\title{
Invertebrate Synapsins: A Single Gene Codes for Several Isoforms in Drosophila
}

\author{
Bert R. E. Klagges, Gertrud Heimbeck, Tanja A. Godenschwege, Alois Hofbauer, Gert O. Pflugfelder, \\ Rita Reifegerste, Dietmar Reisch, Michael Schaupp, Sigrid Buchner, and Erich Buchner
}

Theodor-Boveri Institut für Biowissenschaften der Universität Würzburg, Lehrstuhl für Genetik, Am Hubland, D-97074

Würzburg, Germany

\begin{abstract}
Vertebrate synapsins constitute a family of synaptic proteins that participate in the regulation of neurotransmitter release. Information on the presence of synapsin homologs in invertebrates has been inconclusive. We have now cloned a Drosophila gene coding for at least two inferred proteins that both contain a region with $50 \%$ amino acid identity to the highly conserved vesicle- and actin-binding " $\mathrm{C}$ " domain of vertebrate synapsins. Within the $C$ domain coding sequence, the positions of two introns have been conserved exactly from fly to human. The positions of three additional introns within this domain are similar. The Drosophila synapsin gene $(S y n)$ is widely expressed in the nervous system of the fly. The gene products are detected in all or nearly all conventional synaptic terminals. A single amber (UAG) stop codon terminates the open reading frame (ORF1) of the most abun-
\end{abstract}

dant transcript of the Syn gene 140 amino acid codons downstream of the homology domain. Unexpectedly, the stop codon is followed by another 443 in-frame amino acid codons (ORF2). Using different antibodies directed against ORF1 or ORF2, we demonstrate that in the adult fly small and large synapsin isoforms are generated. The small isoforms are only recognized by antibodies against ORF1; the large isoforms bind both kinds of antibodies. We suggest that the large synapsin isoform in Drosophila may be generated by UAG read-through. Implications of such an unconventional mechanism for the generation of protein diversity from a single gene are discussed.

Key words: synapse; synapsin; C domain; evolution; invertebrates; Drosophila
Release of neurotransmitter from presynaptic nerve terminals involves complex molecular mechanisms effecting the movement of transmitter-loaded vesicles to the presynaptic membrane, the docking of the vesicles at release sites, the priming of docked vesicles for exocytotic competence, the calcium-triggered fusion of vesicular and presynaptic membrane to secrete the transmitter into the synaptic cleft, and the reuptake of the vesicular membrane by endocytosis. However, the molecular details of these mechanisms are still primarily speculative, although the components involved are under intensive investigation (Jahn and Südhof, 1994; Scheller, 1995; Südhof, 1995). One of the best-studicd groups of molecules of vertebrate synaptic terminals is the synapsins, a small family of synaptic vesicle-associated phosphoproteins. The four known isoforms, synapsin-Ia,b and synapsin-IIa,b, are generated by alternative splicing of transcripts from two genes

Reccived Oct. 10, 1995; revised Feb. 5, 1996; accepted Feb. 12, 1996.

This work was funded by Deutsche Forschungsgemeinschaft Grants Bu 566/6 to E.B. We thank Drs. P. C. Emson for the kind gift of neuropeptide antisera, B. Schmidt for one of the cDNA librarics, S. Albert for RNA blots, D. Dudaczek for excellent technical help, C.-F. Wu and T. Südhof for valuable comments on this manuscript, and M. Heisenberg for his permanent support throughout this project. Some of the fly strains used in this work were kindly provided by the Drosophila Stock Centers at Umea, Sweden, and Bloomington, IN.

B.R.E.K. and G.H. have contributed equally to this publication.

Correspondence should be addressed to Dr. Erich Buchner, Theodor-Boveri Institut für Biowissenschaften, Lehrstuhl für Genetik, Am Hubland, D-97074 Würzburg, Germany.

Dr. Heimbeck's present address: Institut de Zoologie, Université de Fribourg, Pérolles, CH-1700 Fribourg, Switzerland.

Dr. I Iofbauer's present address: Institut für Zoologic, Universität Regensburg, Universitätsstrasse 31, D-93047 Regensburg, Germany.

Dr. Reifegerste's present address: Department of Biological Sciences, University of Southern California, Los Angeles, CA 90089-1340.

Copyright (C) 1996 Society for Neuroscience $0270-6474 / 96 / 163154-12 \$ 05.00 / 0$
(Südhof et al., 1989; Südhof, 1990). Mainly on the basis of in vitro experiments, these proteins were generally assumed to play a major role in the short-term regulation of neurotransmitter release and in the maturation of synaptic contacts during synaptogenesis (Bähler et al., 1990; DeCamilli et al., 1990; Benfenati et al., 1991; Chin et al., 1995; Ferreira et al., 1995; Pieribone et al., 1995; Valtorta et al., 1995). In specific experimental situations, dephosphorylated synapsin-I appears to restrict the availability of transmitter-loaded synaptic vesicles for exocytotic release by interlocking the vesicle membrane with actin filaments, thereby arresting the vesicles in the cytoskeletal meshwork. Depolarization of the nerve terminal leads to phosphorylation of synapsin-I and thus may release the vesicles from the cytoskeleton, transferring them from a "reserve" to a "releasable" pool. In this way, the amount of transmitter available at the presynaptic membrane could be regulated by the synapsins (Llinas et al., 1991; Benfenati and Valtorta, 1993). However, the importance of synapsins for basic synaptic function and their involvement in the development of synaptic contacts has recently been questioned, because mouse knock-out mutants lacking synapsin-I, -II, or both genes show rather normal development and behavior. Observed phenotypes in these animals include a tendency to show seizures, altered distribution of synaptic vesicles in presynaptic terminals, decreased transmitter release, and specific defects in neuronal plasticity (Rosahl et al., 1993; 1995; Li et al., 1995).

The high conservation within the vertebrate radiation found for all known proteins associated with synaptic terminals and the fact that homologs have been detected for most of them in Drosophila and/or Caenorhabditis suggest that synaptic transmission as a fundamental mechanism of intercellular communication has been 
conserved in evolution between vertebrates and invertebrates. This is an important issue, because the close morphological and electrophysiological similarity of vertebrate and invertebrate synapses has always been invoked to justify the extensive use of invertebrate model systems for the general study of synaptic function. It was therefore unsatisfying that previous attempts to isolate a Drosophila gene homologous to the vertebrate synapsin gene family have been unsuccessful, although proteins cross reacting with antibodies against vertebrate synapsins have been described both in Drosophila and Aplysia (Mitschulat, 1989; Bongiovi et al., 1992). Our present results demonstrate the existence of a synapsin homolog gene in Drosophila and the conservation of the central vesicle- and actin-binding " $\mathrm{C}$ " domain between flies and mammals. Immunochemical analysis of fly head homogenates and cDNA-encoded protein fragments expressed in bacteria suggests that in Drosophila, different synapsin homolog isoforms may be generated from a single gene by a mechanism of partial suppression of a UAG stop codon separating two large open reading frames.

Some of the data have been published previously as meeting abstracts (Heimbeck et al., 1990; Klagges et al., in press).

\section{MATERIALS AND METHODS}

\section{cDNA and genomic library screening}

The first Syn cDNA was isolated in a screen of 250,000 plaque-forming units (pfu) of a Drosophila head $\lambda \mathrm{gt} 11$ cDNA expression library (wildtype Berlin-K) (as described by Young and Davis, 1985) attributable to a cross reaction of a polyclonal antiserum against a synthetic neuropeptide (antiserum HHA-09 kindly provided by P. Emson). Using the $1.1 \mathrm{~kb}$ $5^{\prime}-E c o$ Rl tragment $\left(S y n-1^{+}\right.$in Fig. 6) of this $1.6 \mathrm{~kb}$ cDNA clone as randomly primed probe (Feinberg and Vogelstein, 1983; Amersham protocol) for hybridization screening of $200,000 \mathrm{pfu}$ of the same cDNA library, 12 additional cDNA clones were obtained. A 400 bp BamHI fragment (containing a central region of the synapsin homology) of the longest of these cDNAs ( $S y n-l$ in Fig. 6) was used as a probe $(P 3$ in Fig. 6) for screening 200,000 pfu of a second head cDNA library ( $\lambda Z a p$ wild-type Canton-S, Stratagene). This screen resulted in the isolation of nine additional cDNAs.

cDNA fragment Syn-1 ${ }^{+}$(see Fig. 6) was also used as a randomly primed probe for screening a $\lambda$-Fix genomic library (wild-type Berlin-K) The cloned genomic walk was extended by additional screening of a $\lambda$-Gem-11 library (wild-type Oregon-R, kindly provided by K. Kaiser), resulting in a cloned genomic region of nearly $56 \mathrm{~kb}$.

\section{Subcloning and sequencing of cDNAs and genomic fragments}

Phage DN $\Lambda$ was isolated and EcoRI fragments were inserted into pBluescript KS vectors according to Sambrock et al. (1989) or according to the Stratagene in vivo excision protocol. Templates were sequenced by the dideoxy method of Sanger et al. (1977) using modified T7 polymerase (Pharmacia) or Sequenase 2.0 (United States Biochemicals). Unidirectional deletions of cDNA clones were created by the method of Henikoff (1987) and sequenced from both strands. Genomic clones were sequenced directly with synthetic oligonucleotide primers. As a control against cloning artifacts, native genomic Drosophila DNA was amplified by PCR using one unmodified and one biotinylated oligonucleotide primer. DNA strands of amplified DNA were separated according to the Dynabeads-M280 protocol (Dynal) and sequenced using Sequenase-2.0 (United States Biochemicals). Sequence data were analyzed using the
DNASIS/PROSIS (Pharmacia) and the GCG (University of Wisconsin, Madison, WI) program packages.

\section{Preparation of fusion proteins and antisera}

Fusion proteins were produced using the glutathione-S-transferase (GST) expression vector system (Pharmacia) in E. coli DH5 $\alpha$ (sup $^{-}$) and BL21 (sup ${ }^{-}$) cells. DH5 $\alpha$ cells contain a UAG suppression tRNA gene (sup E44) and are thus able, albeit with low efficiency, to read through UAG stop codons. cDNA fragments (see Figs. 1 and 6 ) were cloned in frame to GST by using the corresponding pGex vector version. Fusion proteins consisting of the $26 \mathrm{kDa}$ GST carrier and the different SYN proteins were induced and purified as described by Smith and Johnson (1988).

Mice were injected with different amounts $(1 \mu \mathrm{g}$ up to $11 \mu \mathrm{g})$ of $5^{\prime}$ fusion protein and $3^{\prime}$-fusion protein (see Fig. 6) and boosted after 3 weeks. Antisera were collected the next week. Fusion of spleen cells with myeloma cells and isolation of a SYN-specific hybridoma cell line were performed according to standard protocols (Peters and Baumgarten, 1990).

\section{Immunohistochemistry}

Adult flies. Immunostaining of frozen sections was performed as described previously (Buchner et al., 1986). Flies were fixed for 3 hr in $4 \%$ paraformaldehyde and washed overnight in $25 \%$ sucrose solution. Sections were cut on a cryostat microtome at $10 \mu \mathrm{m}$ thickness and incubated at $4^{\circ} \mathrm{C}$ with primary antisera or the primary monoclonal antibody at dilutions of $1: 1000$ or 1:4, respectively. The staining procedures followed the protocol of the biotin-avidin-peroxidase system (Vector Laboratories). Specificity of antibody staining was verified by appropriate controls (e.g., omission of primary antibody).

Lanae. After immobilization at $4^{\circ} \mathrm{C}$, late third instar larvae of WT Berlin- $K$ strain were pinned to a layer of transparent silicone rubber (Sylgard) and cut open as described by Jan and Jan (1976) under a drop of IIL3 solution (Stewart et al., 1994). The preparations were fixed overnight in phosphate buffered $4 \%$ paraformaldehyde and washed three times in a large volume of PBS. The staining procedure followed the biotin-avidin-peroxidase protocol (Vector Laboratories) as described previously (Buchner et al., 1986). After incubation for $2 \mathrm{hr}$ in diluted normal horse serum containing $0.1 \%$ Triton $\mathrm{X}-100$, the monoclonal antibody SYNORF1 (dilution 1:100) was applied for $48 \mathrm{hr}$ at $4^{\circ} \mathrm{C}$ and visualized by using a biotinylated secondary antibody, the avidin-peroxidase complex, and DAB as chromogen.

\section{In situ hybridization}

Head sections. cDNA fragment Syn-1- (Fig. 6) was used as template for the generation of a ${ }^{35}$ S-labeled RNA probe that was hybridized to Drosophila head sections. Preparation of frozen sections and hybridization followed the protocol of Hafen et al. (1983). Contact autoradiographs were obtained by compressing a microscope slide carrying the dried sections and an emulsion-coated slide prepared by dipping in Ilford L4 liquid emulsion and thorough drying. After exposure, the slides were separated, the films developed, and autoradiographs and sections observed simultaneously on a two-stage microscope (Leitz).

Embryo whole mounts. Digoxygenin (DIG)-labeled DNA probes were generated using cDNA Syn-1 as template according the DIG-DNA labeling protocol (Boehringer Mannheim) and hybridized to embryo whole mounts. Preparation of the embryos and hybridization was performed according to Tautz and Pfeifle (1989). Components of the DIGDNA Detection Kit (Boehringer Mannheim) were used for the staining procedure. Embryos were incubated for $1 \mathrm{hr}$ at $4^{\circ} \mathrm{C}$ in a $1: 400$ dilution of the phosphatase-conjugated antibody. After washing four times in PBS $\left(130 \mathrm{mM} \mathrm{NaCl}, 7 \mathrm{mM} \mathrm{Na} 2 \mathrm{HPO}_{4}, 3 \mathrm{~mm} \mathrm{NaH} \mathrm{PO}_{4}, \mathrm{pH} 7.4\right)$, whole mounts

\footnotetext{
Figure 1. Nucleotide sequence of Syn-1 (a) and Syn-2 $(b)$ cDNAs and inferred protein sequence (one-letter amino acid code). Bold amino acids (nt 618-1544): homology to $C$ domain of vertebrate synapsins. All critical regions have been verified by genomic sequencing, including the $5^{\prime}$ and $3^{\prime}$ ends (both presumably incomplete) and the two large open reading frames ORF1 and ORF2 delimited by three stop codons (doubly underlined). The two possible translation start codons are underlined (compare Discussion). Intron positions are indicated by arrowheads. Asterisks mark serine and proline repeats. Arrows are shown below the first amino acids of the $5^{\prime}$ - and $3^{\prime}$-fusion proteins (FP), respectively. The following deviations from the cDNA sequence (clranges in inferred protein in parentheses) have been noted in the genome: 1451: A to G (N to D); 1875-1877 missing (dclctcs P); 3284 : A to T; 3606-3608: missing (no changes). Differences to Syn-1 are underlined in $b$. The nucleotide sequence data reported here will appear in the EMBL, Genbank, and DDBJ nucleotide sequence databases under the accession numbers X95453 (Syn-1) and X95454 (Syn-2).
} 
a)

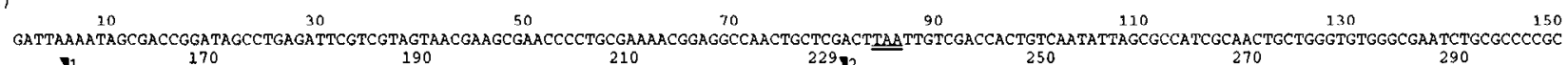

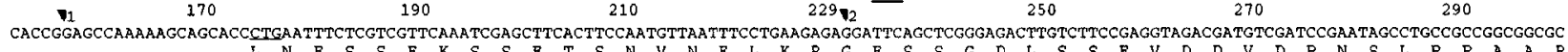

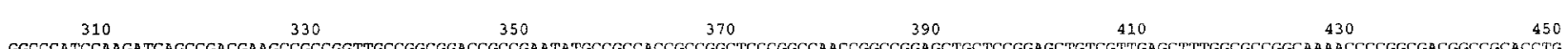

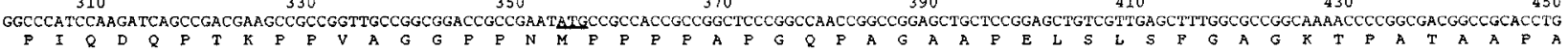

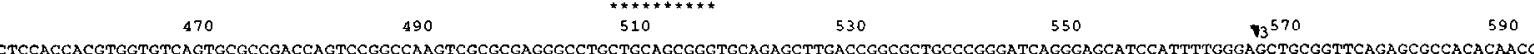

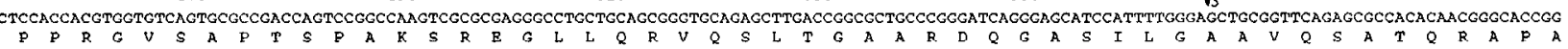
$\begin{array}{llllllll}610 & 630 & 650 & 670 & 690 & 710 & 725 & \mathbf{P}_{4}\end{array}$ CATTCAGCAAGGACAAGTACTTCACGCTGCTGGTTTTGGATGACCAGAACACGGACTGGTCCAAATACTTCCGGGCAGGCGCTTGCACGGCGACTTCGACATCCGAGGGAGCAGGCCGAGTTTAGGGACATTACGGTGGTCTCCAGCG

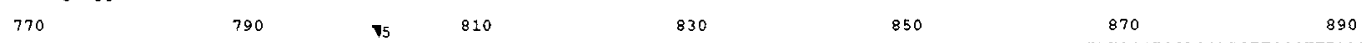

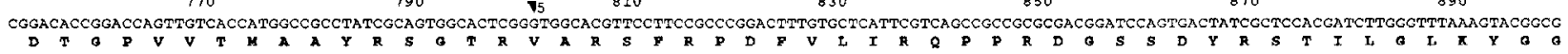

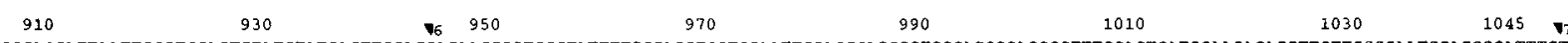
GAGTGCCCAGCATTAATTCGCTGCACTCTATCTATCAGTTCCAGGACAAGCCCTGGGTATTTTCGCACCTGCTGCAATTGCAGCGACGCCTCGGACGCGACGGCTTTCCACTGATCGAACAGACCTTCTTCCCCAATCCACGCGATTTGT

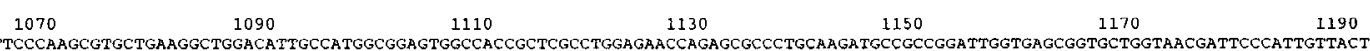
TCCAATPCACCAAGTTCCCAAGCGTGCTGAAGGCTGGACATTGCCATGGCGGGGTGGCCACCGCTCGCCTGGAGAACAGGGCGCCCTGCAAGATGGCGCCGGATTGGTGAGCGGTGCTGGTAACGATTCCCATTGTTACTGCACCATCG

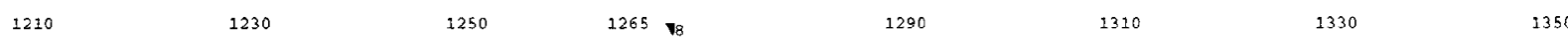
AGCCCTATATCGATGCCAACTTCAGCGTCCACATCCACAACATTCCCAACAACTACAACGCCTTTATCCCCAAATCCATCACCCGCAATTCCAACACCAATCACGCATCCGCCATGCTGGAGCAAATCACTTPAACCGAGAAGTACA.AAA

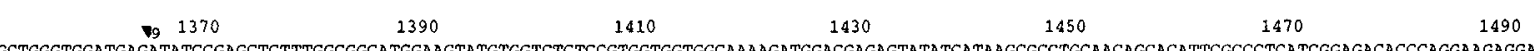

GCTGGGTGGATGAGATATCCGAGCTCTTTGGCGCATGGAAGTATGTGGTCTCTCCGTGGTGGTGGCAAAAGATGGACAGAGTATATCA TAAGCGCCTGCAACAGCACATTCGCCCTCATCGGAGACACCAGGAAGAGGATCGCAGGC $\begin{array}{llllllll}1510 & 1530 & \nabla 10 & 1550 & 1570 & 1590 & 1610 & 1630\end{array}$

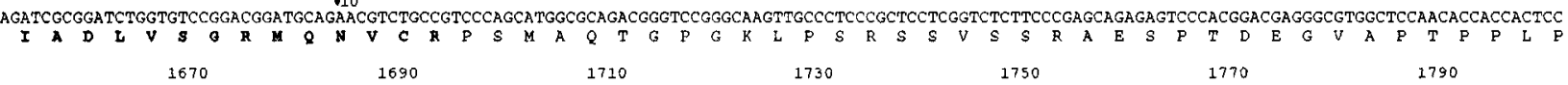

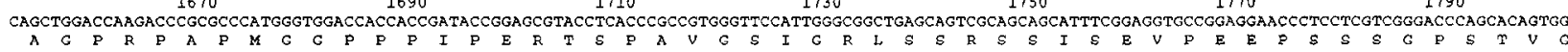

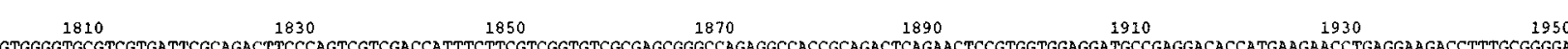

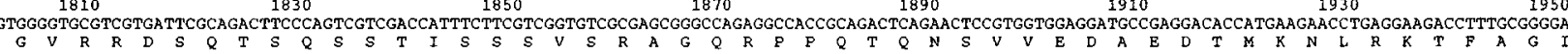

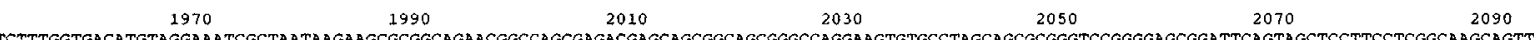

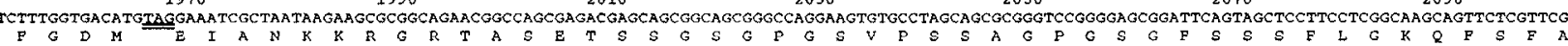

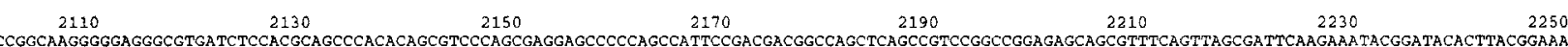

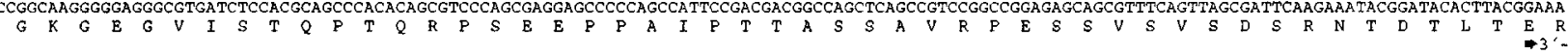

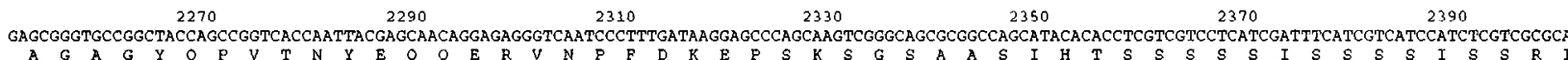

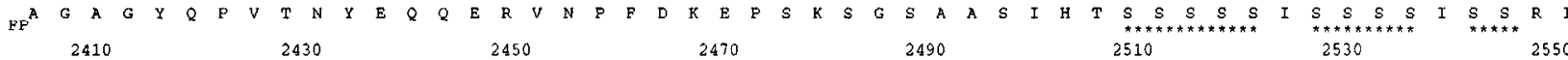

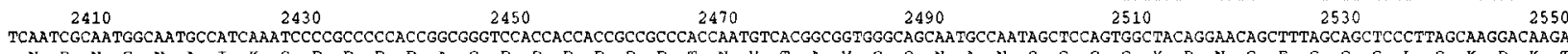

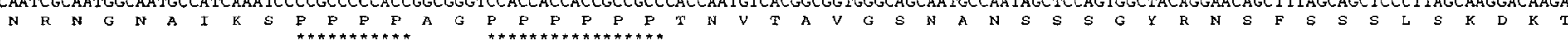

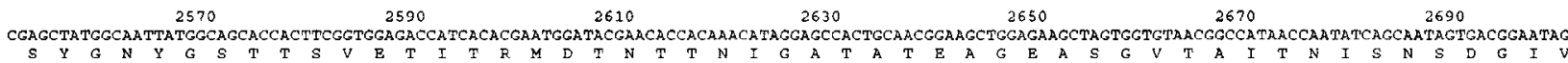

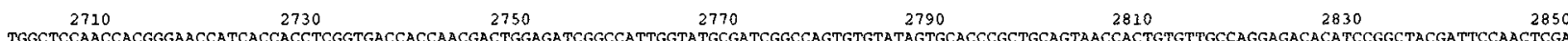
TGGCTCCAACCACGGGAACCATCACCACCTCGGTGACCACCAACGACTGGAGATCGGCCATTGGTATGCGATCGGCCAGTGTGTATAGTGCACCCGCTGCAGTAACCACTGTGTTGCCAGGAGACACATCCGGCTACGATTCCAACTCGA

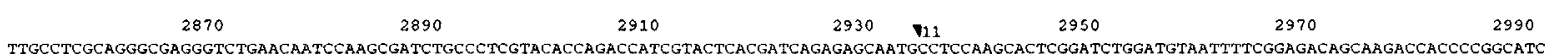
TTGCCTCGCAGGGCGAGGGTCTGAACAATCCAAGCGATCTGCCCTCGTACACCAGACCATCGTACTCACGATCAGAGAGCAATGCCTCCAAGCACTCGGATCTGGATGTAATTTTCGGAGACAGCAAGACCACCCCGGCATCCTATGGAA

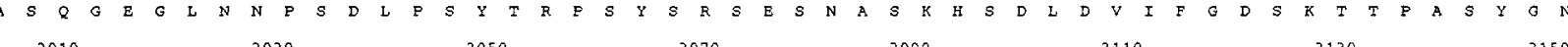

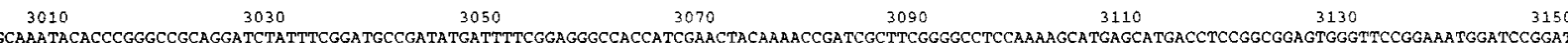

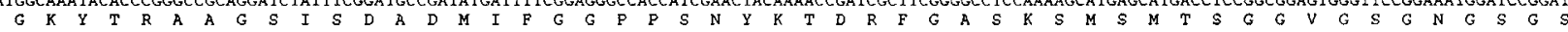

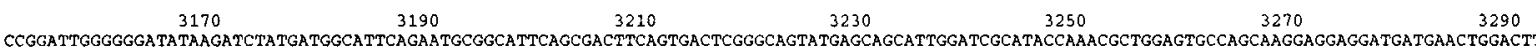

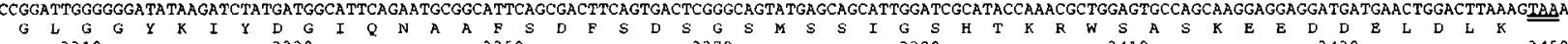
330
TCCAAGGAAATCCAAAGTAGAACTATCAGAACTACAGAAAACATTCACACACACACTAGAGCAACCAAACTA TTGAATTCTATCTACTTTCTGCCTCTGAAGTTTCCTGGTTTCATGCGAAAAACACTAAGCATATACTCACTCACAC
3330

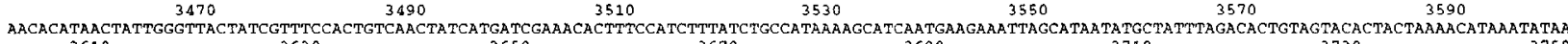

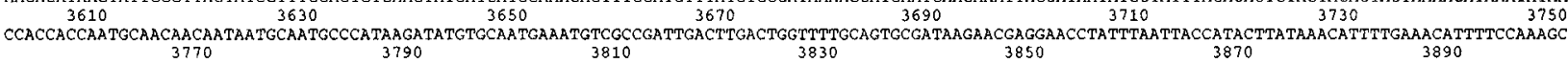

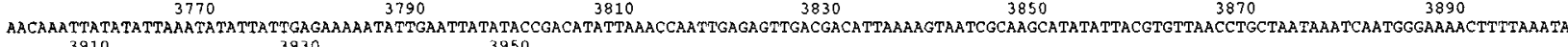
3910
AatcGaATATAATAAATCTGTTATATACCAACATGAGACACATATGAaATCCTAAAAAC

b)

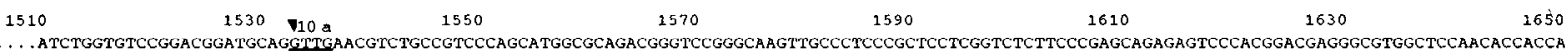

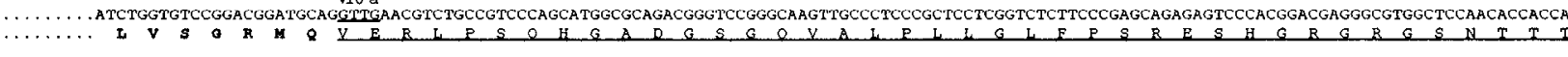
1670 $1690 \quad 1710 \quad 1730 \quad 1750 \quad 1770 \quad 1790$ CTCCCAGCTGGACCAAGACCCGCGCCCATGGGTGGACCACCACCGATACCGGAGCGTACCTCACCCGCCGTGGGTTCCATTGGGCGGCTGAGCAGTCGCAGCAGCATTTCGGAGGTGCCGGAGGAACCCTCCTCGTCGGGACCCAGCACA

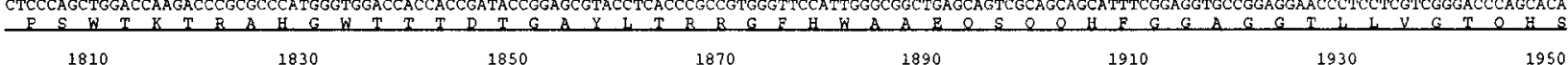

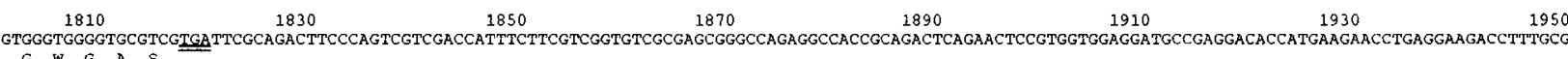

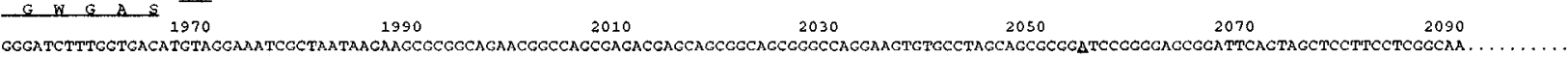

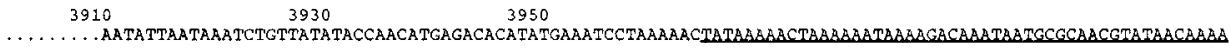




\begin{tabular}{|c|c|c|c|c|c|}
\hline & & & & & \\
\hline & YFTLLVLDDQ & NTDWSKYFRG & RRLHGDFDIR & GEQAEFRDIT & VVSSADTGPV \\
\hline & $|1|: \mid::$ & $:|1|:|1|: \mid$ & $:::||::||:$ & $1|1| 1: 1::$ & $: 1: \mid:: 1$ \\
\hline & ARVLLVIDEP & HTDWAKYFKG & KKIHGEIDIK & VEQAEFSDLN & LVAHANGGFS \\
\hline & SRVLLVIDEP & HTDWAKYFKG & KKIHGEIDIK & $\begin{array}{l}\text { VEQAEFSDLN } \\
\text { AS } 2\end{array}$ & LVAHANGGFS \\
\hline & VTMAAYRSGT & RVARSFRPDF & $V L I R Q P-P R$ & DGSSDYRSTI & LGLKYGGVPS \\
\hline & $1: 1:: 1: 1:$ & $: 1: 11:: 111$ & |||| $\mid:$ : : & $:::|1| 1:$ & $: 11: 1: 1: 11$ \\
\hline & VDMEVLRNGV & KVVRSLKPDF & VLIRQHAFSM & ARNGDYRSLV & IGLQYAGIPS \\
\hline & VDMEVLRNGV & $\begin{array}{c}\text { KVVRSLKPDF } \\
\text { AS3 }\end{array}$ & VLIRQHAFSM & ARNGDYRSLV & IGLQYAGIPS \\
\hline & INSLHS IYQF & $\begin{array}{l}6 V \\
\text { QDKPWVFSHL }\end{array}$ & LQLQRRLGRD & GF FLIde & PNPRDLFQFT \\
\hline & $:|||||:|: \mid$ & ||||||$::=$ & $::|:::| 1:$ & $:|1| 1:|1|:$ & $|1:::::|$ \\
\hline & VNSLHSVYNF & CDKPWVFAQM & VRLHKKLGTE & EFPLIDQTFY & PNHKEMLSST \\
\hline & VNSLHSVYNE & $\begin{array}{c}\text { CDKPWVFAQM } \\
\boldsymbol{\Delta} S 4\end{array}$ & VRLHKKLGTE & EFPLIDQTFY & $\begin{array}{c}\text { PNHKEMLSST } \\
\text { A S5 }\end{array}$ \\
\hline & KFPSVLKAGH & CHGGVATARL & ENQSALQDAA & GLVSGAGNDS & HCYCTIEPYI \\
\hline & $::||:||||$ & |: |: : : : : : & $:|1::| 1 \mid$ & $:: \mid:$ & $: 1111: 1$ \\
\hline & TYPVVVKMGH & AHSGMGKVKV & DNQHDFQDIA & SVVA-N--LT & KTYATAEPFI \\
\hline & TYPVVVKMGH & $\begin{array}{c}\text { AHSGMGKVKV } \\
\text { S6 }\end{array}$ & DNQHDFQDIA & SVVA $-\cdots-\cdots \mathrm{T}$ & KTYATAEPFI \\
\hline & DAKFSVHIQK & IGNNYKAFMR & KSITGNWKTN & QGSAMLEQIT & LTEKYKSWVD \\
\hline & $|1|:: 1:: 11$ & $|1:||||:| \mid$ & $:|::||||| \mid$ & $|1| 1|| 1 \mid:$ & $::::|||| \mid$ \\
\hline & DAKYDVRVQK & IGQNYKAYMR & TSVSGNWKTN & TGSAMLEQIA & MSDRYKLWVD \\
\hline & $\begin{array}{l}\text { DAKYDVRVQK } \\
\nabla 9\end{array}$ & $\begin{array}{r}\text { IGQNYKAYMR } \\
\boldsymbol{\Delta} S 7\end{array}$ & TSVSGNWKTN & TGSAMLEQIA & $\begin{array}{c}\text { MSDRYKLWVD } \\
\mathbf{\Delta} S 8\end{array}$ \\
\hline & EISELFGGME & VCGLSVVVAK & DGREYIISAC & NSTFALIGDT & QEEDRRQIAD \\
\hline & $:|1:| 1 \mid::$ & $: 1::::::$ : & $|1|:: 11::$ & $:|::||| \mid$ & $|:| 1:: 1::$ \\
\hline & TCSEIFGGLD & ICAVEALHGK & DGRDHI IEVV & GSSMPLIGDH & QDEDKQLIVE \\
\hline & TCSEIFGGLD & ICAVEALHGK & $\begin{array}{r}\text { DGRDHI IEVV } \\
\boldsymbol{\Delta} S 9\end{array}$ & GSSMPLIGDH & QDEDKQLIVE \\
\hline & $\nabla 10$ & & & & \\
\hline & $\begin{array}{l}\text { LVSGRM-QNV } \\
||::||::\end{array}$ & $\begin{array}{c}\text { CR } \\
1\end{array}$ & & & \\
\hline & LVVNKMTQAL & PR & & & \\
\hline & LVVNKMAOAL & & & & \\
\hline
\end{tabular}

Figure 2. Sequence comparison of 309 amino acids of the inferred Drosophila synapsin homolog protein (SYN) (1) with the $\mathrm{C}$ domain of rat (2) and human (3) synapsin-la. Within this domain, $50 \%$ of the amino acids are identical (I), and another $39 \%$ are similar (:), allowing for conservative amino acid replacements. Arrowheads indicate intron positions. were equilibrated in $5 \mathrm{~mm} \mathrm{MgCl}_{2}, 100 \mathrm{~mm} \mathrm{NaCl}, 100 \mathrm{~mm}$ Tris, $\mathrm{pH} 9.2$, and NBT/BCIP staining reaction was performed according to the protocol.

\section{Western blots}

Frozen Drosophila heads were collected and homogenized in sample buffer on ice. After separation by standard sodium dodecyl sulfatepolyacrylamide gel electrophoresis (SDS-PAGE) (Laemmli, 1970), proteins were transferred to nitrocellulose membranes according to KhyseAndersson (1984). Immunostaining was performed as described in the Proto-Blot protocol (Promega) or according to the enhanced chemiluminescence Western blotting protocols (Amersham).

\section{RESULTS}

\section{Two alternatively spliced cDNAs}

In a search for novel genes expressed in the adult brain of Drosophila, various antibodies selected for neuronal staining in immunohistochemical preparations were used to screen cDNA expression libraries (Zinsmaier et al., 1990; Reifegerste et al., 1993; Reichmuth et al., 1995). The expression patterns of the genes corresponding to the cloned cDNAs were determined by tissue in situ hybridization. One clone that was isolated because of an unspecific cross reaction of one of the antisera hybridized to most of the cellular rind of the fly's brain. This cDNA was used as a probe to isolate 11 additional independent clones from an adult head cDNA library. Sequencing of both strands of the longest cDNA (Syn-1, $3960 \mathrm{bp}$ ) revealed two in-frame potential coding regions (stop to stop) of 626 and 443 amino acids separated by a single TAG stop codon (Fig. 1a). By comparison with the GenEMBL database, the upstream open reading frame was found to contain a central region of 309 amino acids (bold in Fig. 1) showing $50 \%$ identity and $89 \%$ similarity to the C domain of vertebrate synapsins (Südhof et al., 1989) (Fig. 2). Outside this region, no amino acid patterns with significant similarities to synapsins or other known proteins are observed. However, common features of vertebrate and Drosophila synapsins include richness in proline residues and strings of serine residues outside the $\mathrm{C}$ domain. The sites where vertebrate synapsins are phosphorylated by cAMP-dependent protein kinase (PK-A) or $\mathrm{Ca}^{2+}$. calmodulin-dependent kinase I (PK-MI) (P1 in Fig. 9) and the sites for PK-MII (P2, P3) and for a proline-dependent kinase (P4) are not conserved in Drosophila. Nevertheless, at different positions, two consensus patterns for PK-A (R/K-R/K-X-S/T) and 

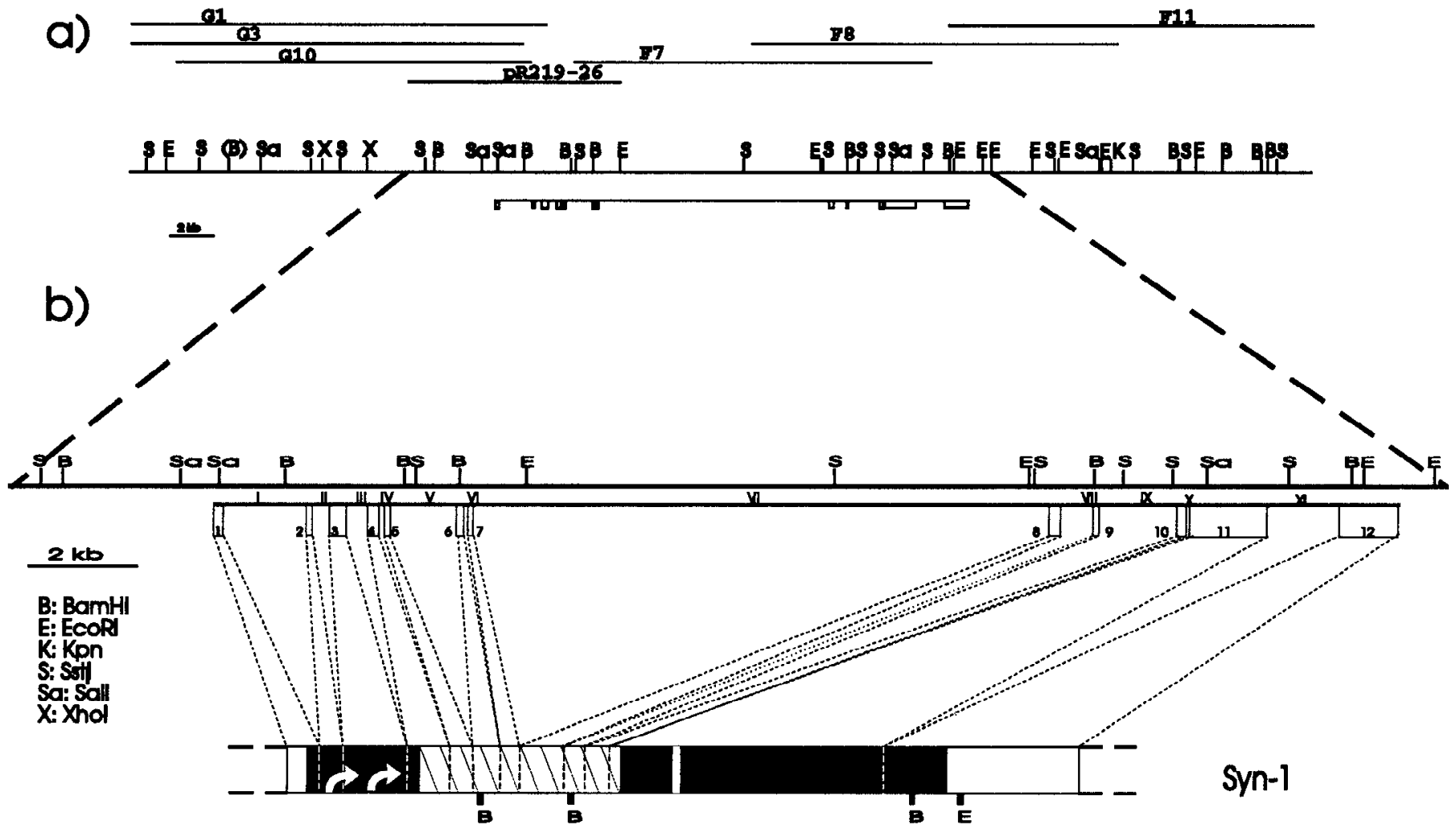

$1 \mathrm{~kb}$

Figure 3. $a$, Restriction map and clones of genomic walk including the Syn gene. Polymorphic restriction sites are in parentheses. $b$, Exon-intron structure of transcript corresponding to Syn-1. Boxes indicate exons. Syn-2 transcript differs from Syn-1 by four bases inserted at the end of exon 10 because of the use of an alternate 5' splice site of intron 10. Homology region is hatched. White bar marks position of internal TAG stop codon. The two possible translation initiation codons (CTG, nt 174; ATG, nt 356) are indicated by curved arrows (compare Discussion).

several for PK-MII (R-X-X-S) or proline-dependent kinase (XS/T-P-X) (Hall et al., 1990) are found in the inferred SYN protein. So far no information is available on the actual phosphorylation pattern of the Drosophila synapsin homolog isoforms.

Probing a second head cDNA library (courtesy B. Schmidt, Max Planck Institut für Hirnforschung, Frankfurt, Germany) with a fragment that encodes the homology domain, another eight independent cDNAs were isolated. Restriction analysis and partial sequencing indicates that, of the $20 \mathrm{cDNAs}$ isolated so far, 11 apparently derive from the same transcript as Syn-1; in particular, all of these contain the central stop codon and show an identical restriction map throughout the coding regions. Three $5^{\prime}$ incomplete cDNAs derive from an alternatively spliced mRNA. The longest of these (Syn-2, Fig. $1 b$ ) begins at nucleotide (nt) 652 of Syn-1 within the homology region. Assuming identical 5 ' ends for Syn-1 and Syn-2 transcripts, Syn-2 contains a potential coding region (stop to stop) of 577 amino acids, 95 of which at the $C$ terminus are different from Syn-1 because of alternative splicing at the $5^{\prime}$ end of intron 10 (Fig. $1 b$ ). The noncoding $3^{\prime}$ end of Syn- 2 contains additional genomically verified $78 \mathrm{bp}$. Interestingly, all three cDNAs of this group display an extra Bam HI site because of an inconsequential single-base exchange at nt 2050 of Syn-1 (see Discussion). The remaining six cDNAs have their $5^{\prime}$ ends downstream of the alternative splice site and thus may belong to either group. Three of these contain at their noncoding $3^{\prime}$ ends a $0.7 \mathrm{~kb}$ extension (not shown) of which only the beginning and the end have been sequenced.

\section{The Syn gene}

Exon-intron structure of the Syn gene was determined by verifying the entire Syn-1 and Syn-2 cDNA sequences (except for a few noncoding regions) in genomic clones (compare Figs. 1 and 3 ). Four differences noted between cDNAs and genome are described in the legend to Figure 1. They may represent polymorphisms in fly stocks or artifacts of reverse transcription or cloning. The known transcribed part of the Syn gene contains 11 introns (Fig. 3). Two introns in the homologous $\mathrm{C}$ domain are found at identical positions in Drosophila and man (Südhof, 1990), and three additional intron positions are similar, as shown in Figurc 2. Some of the exon-intron boundaries (Fig. 4), in particular those of intron 2, differ considerably from the consensus sequence (Senapathy et al., 1990; Mount et al., 1992), even at the most conserved 5' (GT) and $3^{\prime}(\mathrm{AG})$ intron ends.

The Syn gene has been mapped by in situ hybridization to a single site in region $86 \mathrm{~A}$ on the right arm of chromosome 3 (data not shown). Low-stringency Southern blots using the homology region as a probe give no indication of a second homologous gene. We conclude that the Syn gene presumably represents the only synapsin homolog in Drosophila. 


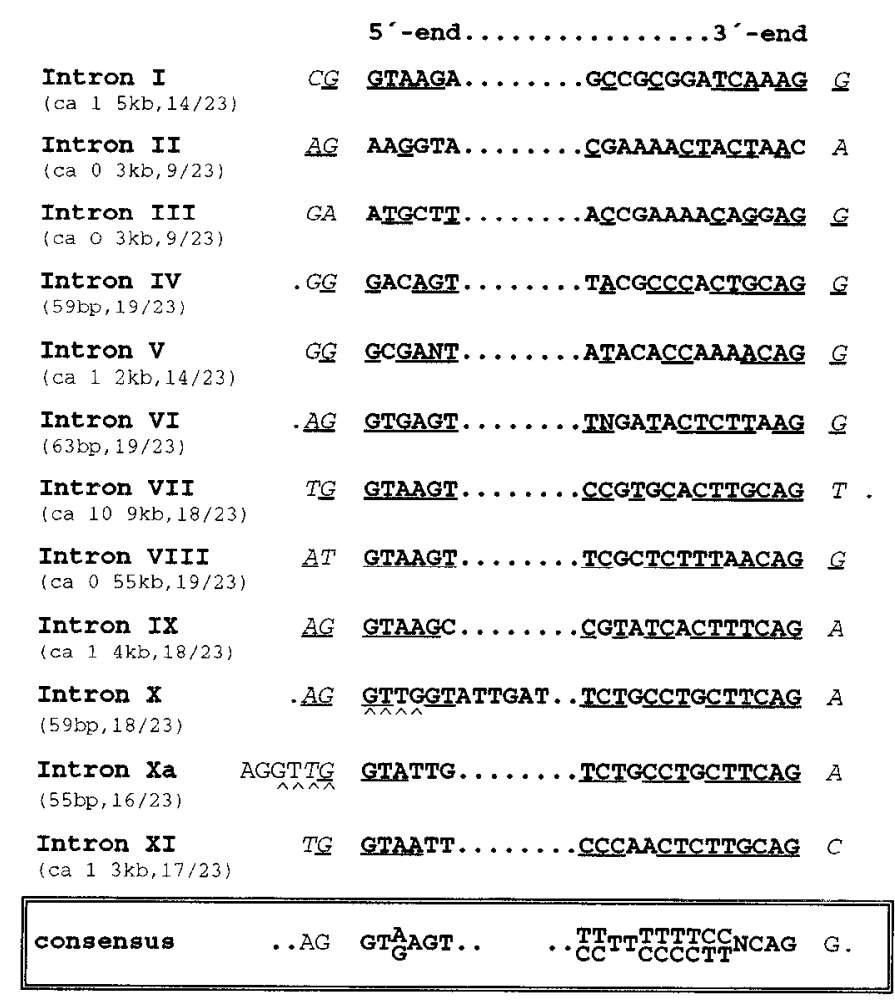

Figure 4 Sequences of exon-intron boundaries compared with consensus sequence (Senapathy et al , 1990, Mount et al , 1992) Bold letters, Introns, taltcs exons Bases in agreement with consensus are underltned Intron size and relative agreement are given in parentheses Alternately spliced basc pairs arc marked by $\wedge$

\section{Expression of the Syn gene}

Transcription of the Syn gene was investigated by Northern blots and tissue $t$ situ hybridization Using probes P1, P2, and P3 from cDNA Syn-1 (compare Fig 6), consistent and about equally strong Northern signals near 55 and $19 \mathrm{~kb}$ are detected at all developmental stages after mid-embryogenesis (data not shown) Because c.DNA Syn-1 is incomplete at a known length of $3960 \mathrm{bp}$ and cDNA Syn-2 may differ from Syn-1 by as little as 4 bp, we assume that both cDNAs are represented in the $55 \mathrm{~kb}$ signal (compare Discussion) Tissue in situ hybridization of embryos (F1g $5 a$ ) and adult head sections (F1g $5 b$ ) demonstrates Syn expression in most or all parts of the nervous system Hybridizatıon to adult photoreceptors and lamina monopolar cells appears considerably weaker than to the rest of the brain cellular rind (Fig $5 b$ )

To determine the size and distribution of polypeptides translated from the Syn gene, we have produced two sets of mouse antisera (AS) against the bacterially expressed GST fusion proteins $5^{\prime}$-FP and $3^{\prime}$-FP (compare Fig 6) The 5'-FP contains most of the $5^{\prime}$ reading frame ORF1 and is encoded by cDNA Syn- $1^{*}$ up to the internal stop including the homolugy region The $3^{\prime}$-FP contains most of the $3^{\prime}$ open reading frames downstream of the stop codon (ORF2) and is encoded by cDNA Syn- $1^{+}$Specificity of the antisera was tested by Western blots of lysates from bacteria expressing either the fusion proteins or only the GST carrier protein Of six mice injected with $5^{\prime}$-FP, five produced AS reacting with both the $5^{\prime}$-FP (control) and the GST carrier, and one serum was negative Spleen cells from one of the positive mice were fused with myeloma cells, and a hybridoma cell line was estab- lished that secretes a monoclonal antıbody recognizing the 5'-FP but not GST (mAb SYNORF1) At least four, probably five, synapsin 1soforms are recognized by mAb SYNORF1 in Western blots of fly head homogenates (lane $\mathrm{H}$ of F1g $7 a$ ) three prominent protein bands of $M_{1}=70,74$, and $80 \mathrm{kDa}$ (SDS-PAGE) and one or two less-abundant proteins of $M_{\mathrm{r}} \sim 143 \mathrm{kDa}$

All six AS generated against the 3 '-FP reacted with this FP (control) and with GST carrier One of these sera was preabsorbed with GST to obtain a serum specific for the reading frame encoded downstream of the central TAG stop (AS SYNORF2) Antiserum SYNORF2 recognizes in fly head homogenates only the two less-abundant proteins of $M_{\mathrm{r}} \sim 143 \mathrm{kDa}$ (lane $H$ of Fig $7 b$ ).

These results can readily be connected to the molecular genetic data described above if we assume that, in the fly, the central UAG stop codon in the mRNA corresponding to cDNA Syn- 1 is partially read through by a specific, as yet unknown mechanism (see Fig 9 and Discussion) We therefore wanted to test how the partial suppression of this stop codon by a known mechanism, $1 \mathrm{e}$, a UAG suppressor tRNA in the $E$ coll expression system, would affect the proteins derived from cDNA Syn-1 For direct compar1son, we transformed with cDNA Syn-1* (Fig 6) both a normal (see $\mathrm{B}^{+}$and $\mathrm{B}^{-}$in $\mathrm{Fig} 7$ ) and a genetically modified $E$ coll strain (see $\mathrm{D}^{+}$in $\mathrm{F}_{1 \mathrm{~g}} 7$ ), the latter containıng a UAG suppressor tRNA gene Extensive tests were performed with all antisera on the various fusion proteins Controls included omission of first antibody (not shown) and comparison of induced $\left({ }^{+}\right)$and noninduced $\left(^{-}\right)$bacteria Figure 7 summarizes the results showing data of the specific antıbodies, mAb SYNORF1 and the GST-preabsorbed AS SYNORF2 mAb SYNORF1 (Fig 7a) recognizes in induced $\sup ^{-}\left(\mathrm{B}^{+}\right)$and $\sup ^{+}\left(\mathrm{D}^{+}\right)$strains a $78 \mathrm{kDa}$ fusion protein (plus presumed degradation products) and, in addition, in the sup $^{+}$ $\left(\mathrm{D}^{+}\right)$strain a $\sim 150 \mathrm{kDa}$ fusion proteın Lysates from nonınduced bacteria show little or no signal ( ${ }^{-}$) AS SYNORF2 (F1g $7 b$ ), on the other hand, only stains the $\sim 150 \mathrm{kDa}$ read-through fusion protein (RT-FP) (plus degradation products), whıch is generated only in the induced sup ${ }^{+}$strain $\left(D^{+}\right)$No specific staining is observed in lysates of the sup ${ }^{-}$stran $\left(\mathrm{B}^{+}, \mathrm{B}^{-}\right)$The large amount of unlabeled 5'-FP of $78 \mathrm{kDa}$ can be recognized in both induced lanes $\left(\mathrm{B}^{+}, \mathrm{D}^{+}\right)$because of a faint cross reaction of the secondary antiserum These tests demonstrate the specificity of mAb SYNORF1 and AS SYNORF2 as they bind only to those parts of the Syn-1-encoded fusion proteins expressed in $E$ colt that were used for immunization The signals in fly homogenates (lanes $H$ in Fig $7 a, b$ ) demonstrate that the $70 / 74 / 80 \mathrm{kDa}$ triplet binds only antibodies against the $5^{\prime}$ reading frame (ORF1), whereas the $\sim 143$ $\mathrm{kDa}$ doublet is recognized by antıbodıes directed against both reading frames, upstream (ORF1) and downstream (ORF2) of the internal TAG stop

Using mAb SYNORF1, we have determined the approximate relative amounts of the $70 / 74 / 80 \mathrm{kDa}$ and the $\sim 143 \mathrm{kDa}$ protems in head homogenates by loadıng increasing amounts of homogenate Figure $7 c$ indicates that the strongest signal of the triplet is about four to five times as abundant as the $\sim 143 \mathrm{kDa}$ proteins

In immunohistochemical experiments, mAb SYNORF1 and all antisera (except the negative serum), regardless of which of the two Syn-1 reading frames they are directed against, show indistinguishable stainıng of most regions of the larval and adult synaptic neuropil and of synaptic boutons on larval and adult muscles (Fig 8) In adult heads, the first optıc neuropil, the lamina, and a certain layer of the medulla [presumably M5, (Fischbach and Dittrich, 1989)] show only very weak stainıng This 


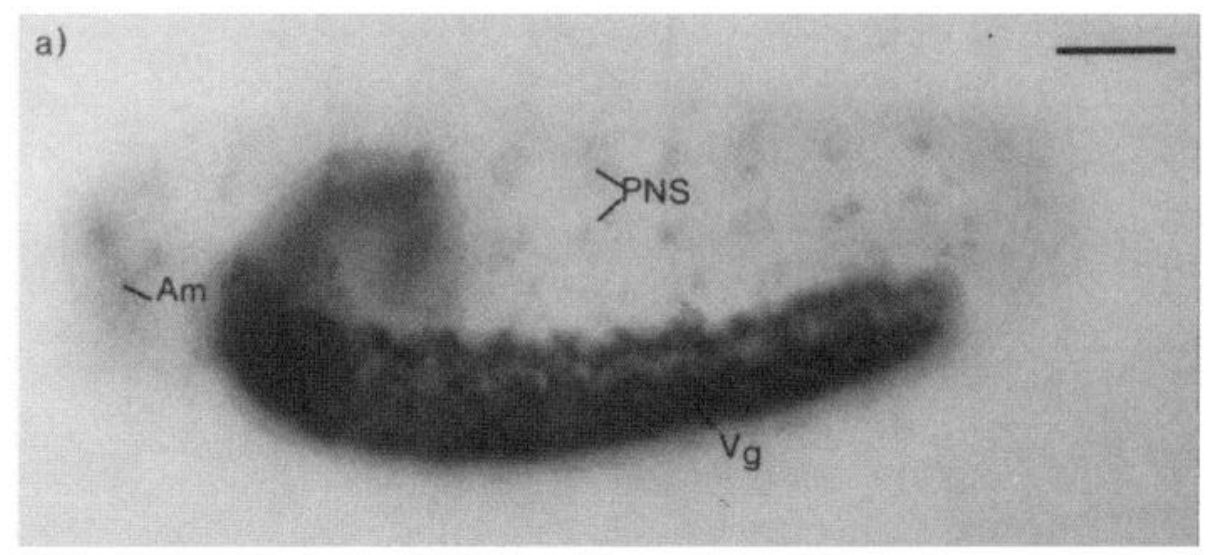

Figure 5. In situ hybridization using cDNA fragments P1 + P2 of Figure 6 as digoxygenin-labeled probe and anti-digoxygenin immunohistochemistry (a) or using cDNA Syn- $1^{+}$as ${ }^{35}$ S-labeled probe and contact autoradiography $(b, c)$. Expression of the Syn gene is evident for most or all parts of the late embryonic nervous system $(a) . b$, Unstained frozen head section to which probe was hybridized. $c$, Contact autoradiograph of section in $b$ showing specific signals for most of the brain cellular rind (chitin binds probe unspecifically). Am, Antennal maxillary complex; $L a$, lamina; $L o$, lobula; $L p$, lobula plate; $M e$, medulla; $P N S$, peripheral nervous system; $R$, retina; $V g$, ventral ganglia. Scale bars: 20 $\mu \mathrm{m}(a)$ and $100 \mu \mathrm{m}(b, c)$.
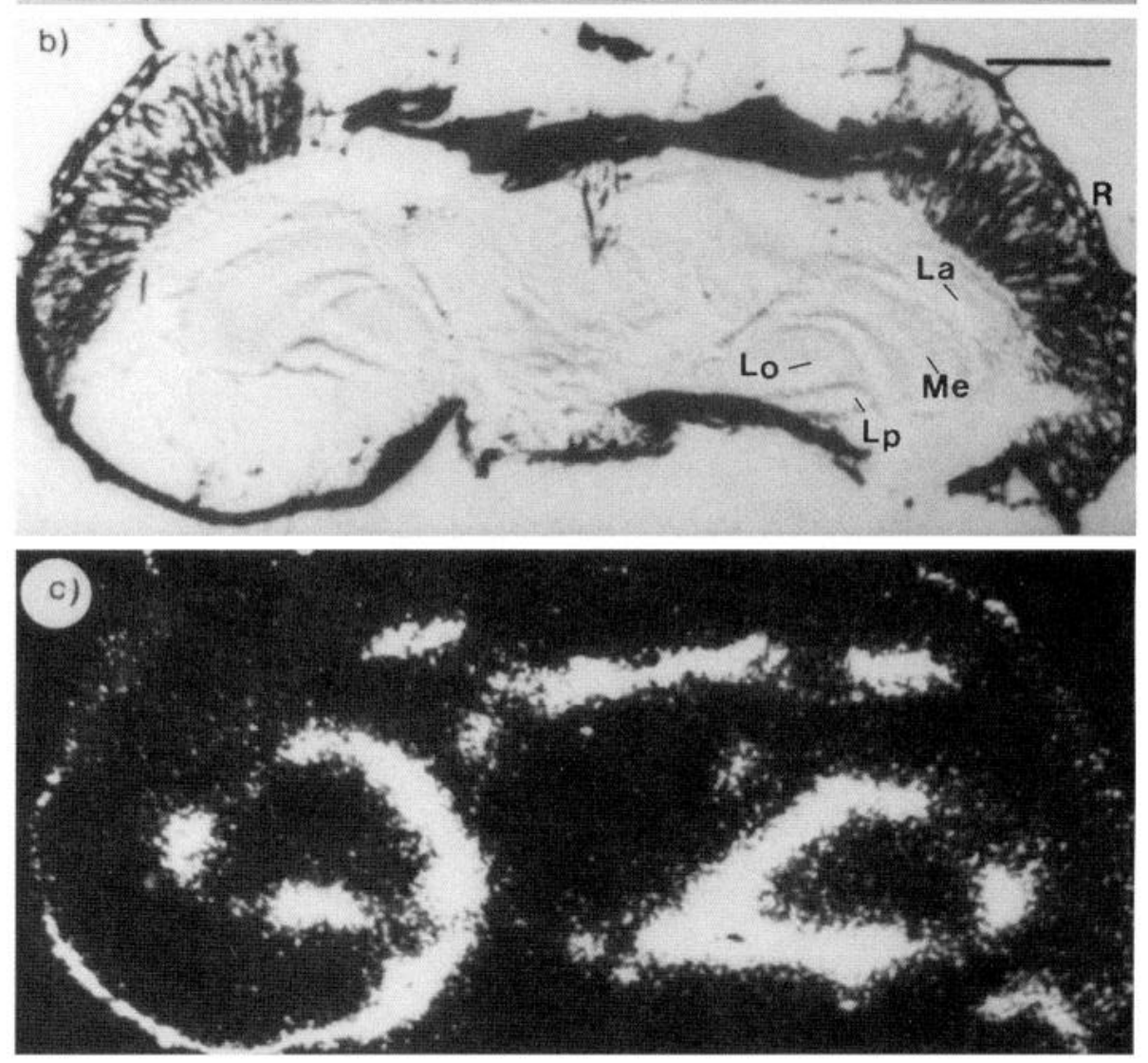

indicates that most synapses of Drosophila contain possibly all five but at least two synapsin isoforms, one of the $70-80 \mathrm{kDa}$ triplet and one of the $\sim 143 \mathrm{kDa}$ doublet. Photoreceptors R1-R6, which have their synapses in the lamina and at least some of the cells with synaptic terminals in or near layer M5 of the medulla (cf. Fischbach and Dittrich, 1989), contain no or very little of the presently known synapsin homolog isoforms.

\section{DISCUSSION}

We have cloned and characterized a gene that encodes proteins with a domain of 309 amino acids that shows $50 \%$ identity to the $\mathrm{C}$ domain of vertebrate synapsins. To our knowledge, this represents the first invertebrate gene with homology to the synapsin phosphoprotein family. Antibody cross reactivity had suggested previously the existence of synapsin-like proteins in Drosophila (Mitschulat, 1989) and Aplysia (Bongiovi et al., 1992). The fact that the homology between synapsins of vertebrates and Drosoph- ila is restricted to the $\mathrm{C}$ domain indicates that this domain is crucial for conserved functions of the synapsins. The interactions of vertebrate synapsins with both the synaptic vesicle membrane and the cytoskeleton have been attributed to this domain, which is common to all known synapsin isoforms (Huttner et al., 1983; Schiebler et al., 1986; Bähler and Greengard, 1987; Südhof et al., 1989; Ceccaldi et al., 1995). Thus, our results further support the notion that basic mechanisms of synaptic transmission and its regulation have been conserved in evolution of both invertebrates and vertebrates.

\section{Transcripts of the Syn gene}

None of the cDNAs isolated so far appears to be full-length. An extensive poly-A tail preceded at the normal distance of 20-30 bp by the polyadenylation consensus signal (Proudfoot and Brownlee, 1976; Birnstiel et al., 1985) is not found in any of the isolated cDNAs. Rather, they either terminate at internal EcoRI sites, 


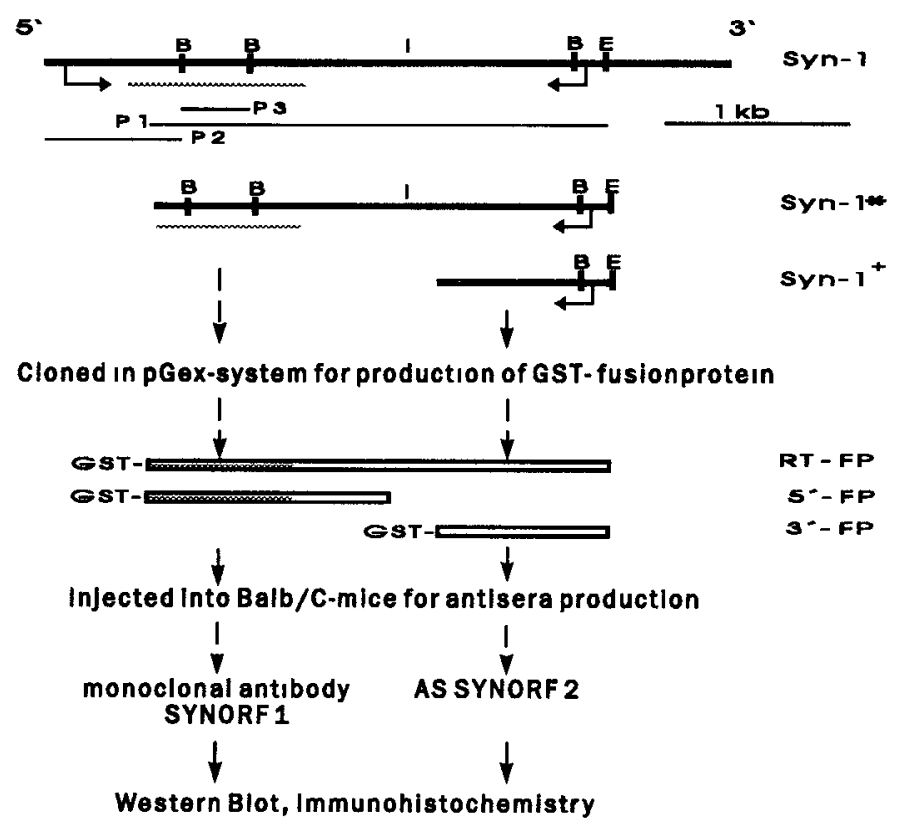

Figure 6 Schematic of cDNA fragments used as hybridization probes $(P 1-P 3)$ or expressed as GST fusion proteins in $E$ coll Fusion proteins $5^{\prime}$-FP and $3^{\prime}$-FP were used for immunization and production of antisera and monoclonal antibodies in mice $\sim \sim$ denotes homology region, $I$ marks the internal stop codon at nt 1965 of cDNA Syn-1, cDNA Syn- $1^{+}$ corresponds to nt 2246-3377, arrows delımit readıng frames (stop to stop) $B, B a m \mathrm{HI}, E, E c o$ RI restriction sites

indicating that these had been incompletely methylated before EcoRI linker attachment during construction of the cDNA library, or their 3 ' ends reside within adenin-rich stretches that may lend themselves to internal oligo-dT priming durıng first-strand cDNA synthesis At the 5' end, no clustering of cDNA terminations is observed and no canonical TATA-box is found in the genomic sequence immediately upstream of the longest cDNA (Syn-1) Thus, the data are consistent with the proposition that the $55 \mathrm{~kb}$ Northern signal represents both mRNAs corresponding to Syn-1 and Syn-2 if we assume that they differ only by the four bases between the alternative splice sites of introns 10 and 10a (Fig 4) Several possibilities exist for the interpretation of the $19 \mathrm{~kb}$ Northern signal It may be caused by alternate transcription initiation, termination, or splicing, leading to an mRNA that, for unknown reasons, is not represented among the 20 cDNAs isolated from two libraries so far, it may correspond to a degradation product of the $55 \mathrm{~kb}$ mRNA, or it may represent an unspecific signal from rRNA not completely removed by polyA ${ }^{+}$RNA preparation Considering the high-stringency wash conditions of the Northern blots, we reject the speculation that the $19 \mathrm{~kb}$ signal might represent an mRNA from a homologous gene, because such a gene would have been detected in low-strıngency Southern blots (data not shown) The two splice variants described here were represented in one library (from WT Berlin) with nume and three copies, respectively, in the other library (from WT CantonS), only the major variant was found ( 8 independent isolates) The extra BamHI site in all three cDNAs of the minor splice variant is conspicuous, but unless this is a mere coincidence, there seems no simple interpretation The question whether the 95 amino acids of the shifted reading frame of exon 11 may be found in one of the stable synapsin homolog isoforms can only be answered by protein sequencing or generation of antıbodies against this 95 amino acid domain Several of the cDNAs isolated here show at their $5^{\prime}$ or $3^{\prime}$ ends short sequences not detected in any other cDNA or the genomic walk of $56 \mathrm{~kb}$ (either by sequencing or by hybridization) Because the transitions from verified to unique sequences exhibit no similarity to the exon-intron boundary consensus, these sequences were considered to be attributable to artefactual ligation of unrelated cDNA fragments during generation of the cDNA libraries and therefore were omitted from the cDNAs shown

\section{The SYN proteins}

Figure 9 illustrates our working hypothesis explaınıng how three of the five SYN isoforms seen in Western blots might derive from the two known cDNAs Syn-1 and Syn-2 SYN1-RT 1s assumed to correspond to one of the $143 \mathrm{kDa}$ doublet isoforms, SYN1-S to the 74 or the $80 \mathrm{kDa}$ 1soform, and SYN2 to the $70 \mathrm{kDa}$ isoform The remainıng two isoforms might represent post-translational modifications of SYN1-RT and either SYN1-S or SYN2 Because no reliable information on the actual translation start in the fly is avalable, the protein sizes given in Figure 9 have been calculated by using the first ATG or the first CTG (in parentheses) after the 5' delimiting stop (TAA) CTG has been described as an alternative translation start codon in Drosophila (Sugihara et al, 1990, Boyd and Thummel, 1993) The four bases upstream of both of these codons show high similarity to the translation initiation consensus of Drosophila genes (Cavener, 1987)

\section{Amber suppression in E. coli supports hypothesis of UAG read-through in the fly}

The hypothesis of Figure 9 is strongly supported by the analysis of the GST fusion proteins in sup ${ }^{-}$and $\sup ^{+} E$ coll strains (Fig 7) The $M_{\mathrm{r}}$ values for Western signals of fusion protcins in $E$ coll $\left(5^{\prime}\right.$-FP, $78 \mathrm{kDa}, 3^{\prime}$-FP, $66 \mathrm{kDa}$, RT-FP, $\left.150 \mathrm{kDa}\right)$ primarily conform to the calculated values $(75,61$, and 120 $\mathrm{kDa}$, respectively), except that the largest read-through protein band is $\sim 30 \mathrm{kDa}$ too large This led to the intriguing observation that the difference between the TAG-terminated and the largest read-through fusion protein signals in $E$ coll $(150-78$ - $72 \mathrm{kDa}$ ) closely corresponds to the difference between the $70 / 74 / 80 \mathrm{kDa}$ triplet and the $\sim 143 \mathrm{kDa}$ doublet signals in the head homogenates. Because the antıbodies demonstrate that the $\sim 143 \mathrm{kDa}$ proteins apparently contain sequences encoded by both the $5^{\prime}$ and the $3^{\prime}$ reading frame of Syn- 1 and because among 11 cDNAs containing both of these reading frames none without the internal TAG stop was found, our working hypothesis incorporates the assumption that, in Drosophila, the UAG stop codon of the mRNA corresponding to cDNA Syn-1 is read through by a tRNA-directed mechanism with an efficiency of $\sim 20-25 \%$ (compare Fig $7 c$ ) Trivial alternative explanations for the TAG stop, such as cloning or sequencing artifacts, can be excluded because the stop codon was verified in 11 independent cDNAs, in genomic clones of different fly strains, and directly in PCR-amplified native DNA A stretch of 443 contiguous amıno acid codons downstream of a stop codon is highly likely to accumulate nonsense mutations unless it is translated into a polypeptide that serves some fitness-relevant function tRNA-directed read-through represents a hypothesis that is compatible with all present data The possibility of natural nonsense suppression in higher eukaryotes, in partıcular in the kelch gene of Drosophlla, has been observed prev1ously (Geller and Rich, 1980, Hatfield, 1985, Xue and Cooley, 1993) In addition, it has been demonstrated that a tRNA ${ }_{G}{ }^{\text {ty }}$ isolated from wild-type Drosophila is capable of directıng sub- 
Figure 7. Western blot analysis of Syn gene expression in Drosophila heads and in two transformed $E$. coli strains, BL21 $(B)$ and DH5 $\alpha(D)$. UAG stop codons are read through at low efficiency in DH5 $\alpha$ cells because of the presence of a UAG suppressor tRNA in this strain $\left(\right.$ sup $\left.^{+}\right)$. BL21 is sup $^{-}, a$, mAb SYNORF1 recognizes in sup ${ }^{-} E$. coli the massively induced fusion protein of $78 \mathrm{kDa}$ (plus degradation products) (induced, $\mathrm{B}^{+}$; noninduced, $\mathrm{B}^{-}$); in $\sup ^{+} E$. coli the 78 $\mathrm{kDa}$ protein; and, in addition, the read-through form of $\sim 150 \mathrm{kDa}$ (induced, $\mathrm{D}^{+}$). In fly heads $(H)$, a protein triplet of 70,74 , and $80 \mathrm{kDa}$ and a doublet at $\sim 143$ $\mathrm{kDa}$ are recognized. $b$, Antiserum SYNORF2 recognizes the $66 \mathrm{kDa} 3^{\prime}$-fusion protein used for immunization ( $3^{\prime}$-FP), the read-through form in sup $^{+}$strains $\left(\mathrm{D}^{+}\right)$, and only the $\sim 143 \mathrm{kDa}$ protein doublet in head homogenates $(H)$. The massively induced $78 \mathrm{kDa}$ protein does not bind this antiserum but is faintly recognizable in the $\mathrm{B}^{+}$and $\mathrm{D}^{+}$lanes because of weak unspecific staining. $c$, Semiquantitative analysis of Western blot signals obtained with mAb SYNORF1 from $1 / 4,1 / 2,1,2$, and 4 heads per lane predict a read-through efficiency of $20-25 \%$ in heads. a) b) c)

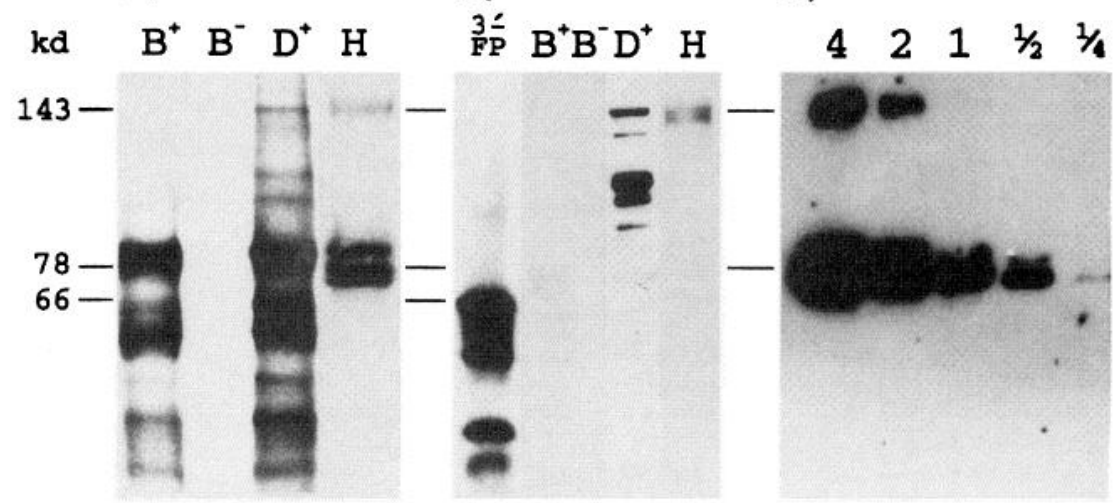

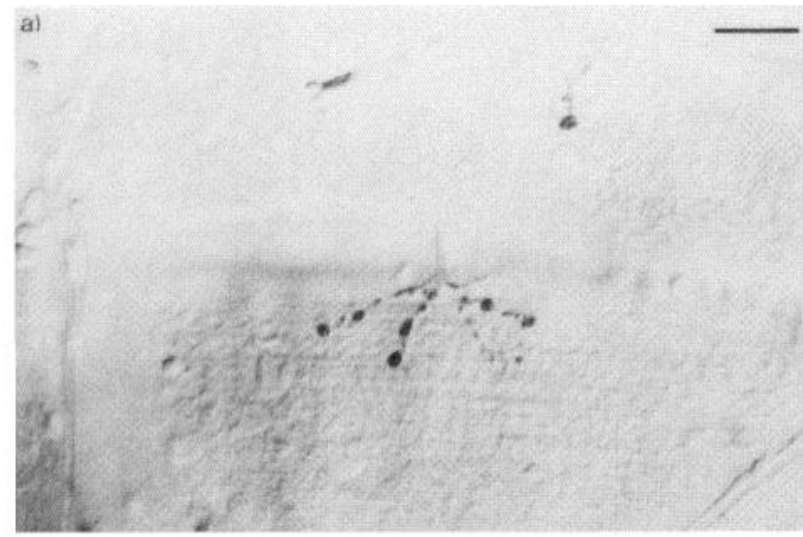
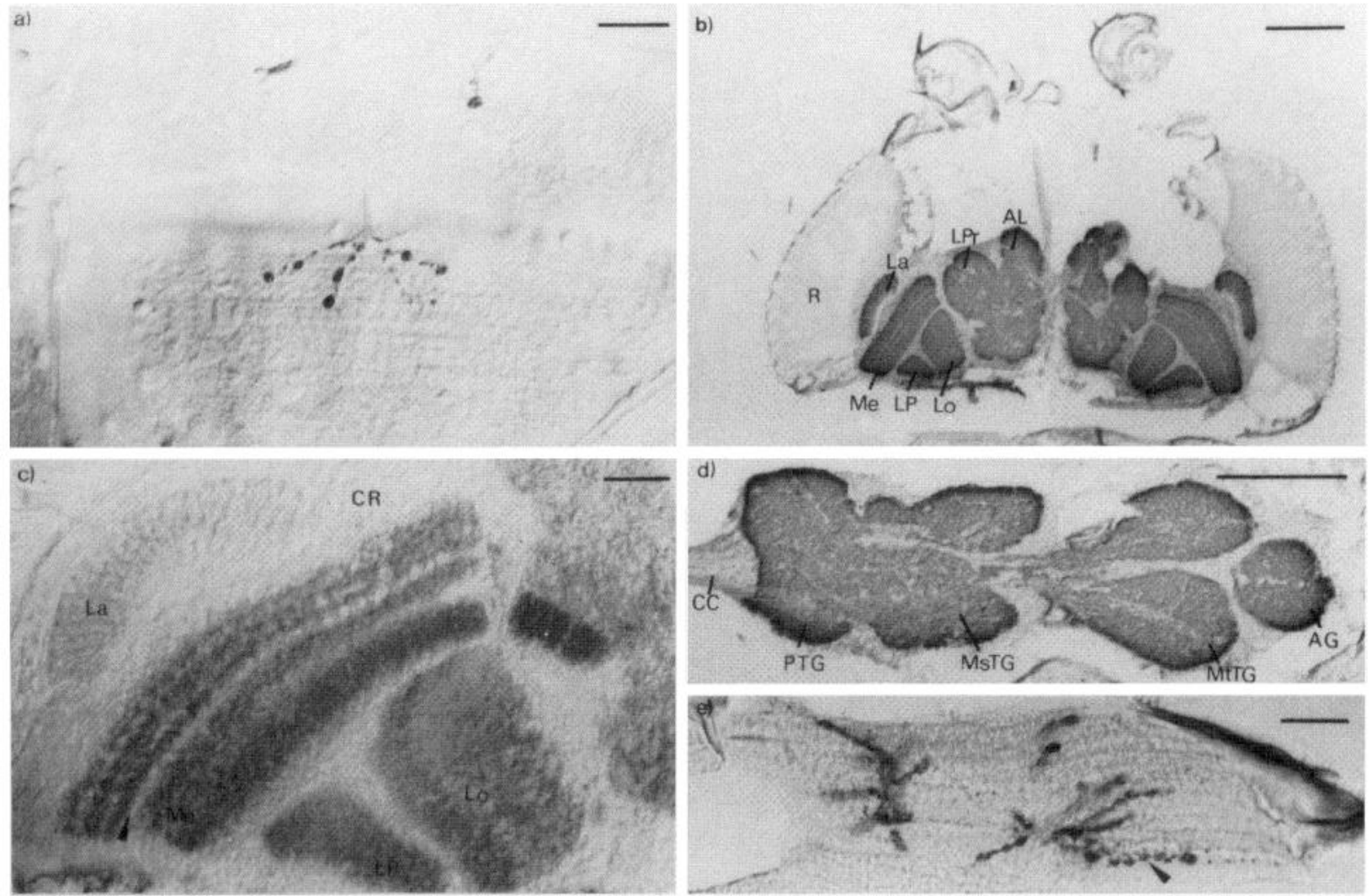

Figure 8. $a$, Immunohistochemical staining by mAb SYNORF1 of synaptic boutons on a larval body wall muscle preparation. $b$, Immunohistochemical staining of a horizontal section through an adult Drosophila head using mAb SYNORF1 (dilution 1:4). Most synaptic neuropil is stained strongly. $c$, Optic lobes stained by using mAb SYNORF1 at 1:150 dilution to show the weaker antibody binding to the lamina $(L a)$ and a layer of the medulla (Me, arrowhead). Axons (between neuropil masses) and perikarya of the cellular rind $(C R)$ are almost devoid of staining. $d, e$, mAb SYNORF1 staining of thoraco-abdominal neuropil $(d)$ and synaptic boutons on a direct-flight muscle $(e)$. Five antisera generated against the $5^{\prime}$-fusion protein $\left(5^{\prime}\right.$-FP) and six antisera against the $3^{\prime}$-FP show staining patterns indistinguishable from those of mAb SYNORF1. $A G$, Abdominal ganglion; $A L$, antennal lobe; $C C$, cervical connective; $C R$, perikarya of cellular rind; $L o$, lobula; $L P$, lobula plate; $L P r$, lateral protocerebrum; $M s T G$, mesothoracic ganglion; $M t T G$, metathoracic ganglion; $P T G$, prothoracic ganglion; $R$, retina. Scale bars: $20 \mu \mathrm{m}(a, c, e)$ and $100 \mu \mathrm{m}(b, d)$.

stantial TAG read-through of tobacco mosaic virus RNA in a heterologous test system, whereas RNA $_{\mathrm{O}}{ }^{\text {tyr }}$ is not (Bienz and Kubli, 1981), indicating that cellular tRNA base modification may regulate read-through translation (Beier et al., 1984).
Germ line transformation of Drosophila with in vitro mutagenized rhodopsin genes demonstrated differential UAG suppression, albeit at very low efficiency, depending on the nucleotide sequence surrounding the stop codon (Washburn 


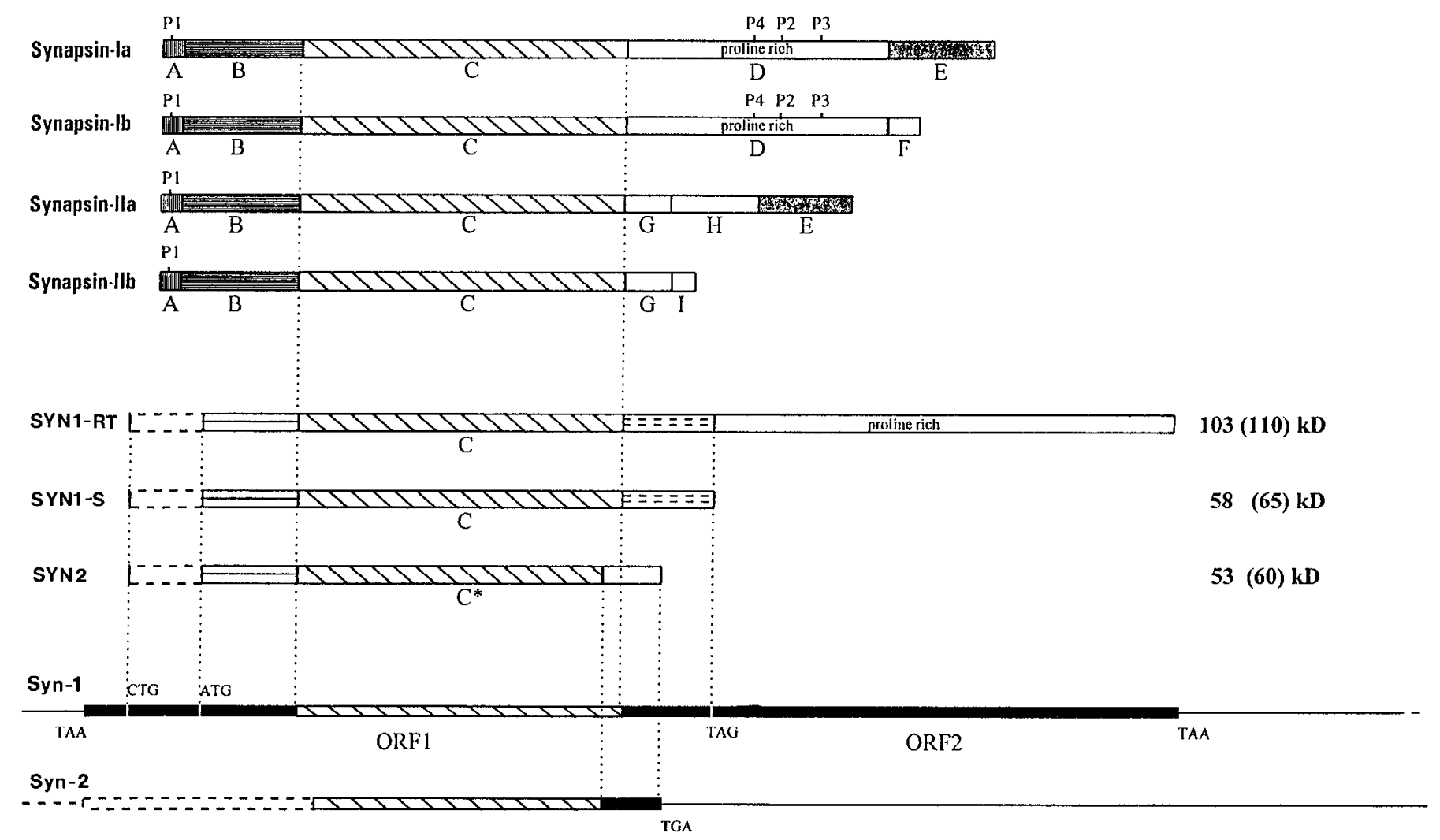

Figure 9. Top, Domain structure of the four vertebrate synapsins [redrawn according to Südhof et al. (1989)]. Domains $A, B$, and $C$ are common to all four vertebrate synapsins, domain $C$ is most highly conserved, and domains $D-I$ are more variable. $P 1-P 4$ denote phosphorylation sites. Bottom, Drosophila cDNAs Syn-1 and Syn-2 with the possible start codons ATG and CTG as well as the stop codons TAA, TAG, and TGA delimiting the large open reading frames (ORF) (broad lines). Broken lines indicate inferred extensions of cloned sequences. Middle, Present hypothesis, how the mRNAs corresponding to Syn-1 and Syn-2 might be translated into SYN proteins by read-through of the central UAG stop codon (SYN1-RT), respecting this stop (SYN1-S), or using the splice variant (SYN2). For each of these three proteins, the calculated molecular weight is given using the first ATG or the first CTG (numbers in parentheses). Note that only domain $C$ (and its truncated version $C^{*}$ in SYN2) is conserved between vertebrates and Drosophila (indicated by oblique hatching).

and O'Tousa, 1992). Recently it has been suggested that two nonsense mutations in the elav locus are read through at relatively high efficiency by an as yet unknown mechanism (Samson et al., 1995). The perfect or near-perfect match of the four nucleotides upstream of the read-through stop codon in the kelch gene, the elav mutant, and the Syn gene may be more than coincidental. Alternative hypotheses to read-through, such as the existence of an edited (Cattaneo, 1991; Sommer et al., 1993; Ruano et al., 1995) or differently spliced mRNA that is not represented among the 20 cDNAs isolated so far, seem less likely but can at present not be excluded. If verified by direct protein sequencing, the molecular mechanism of the proposed TAG read-through in Drosophila and the features of its regulation can be investigated by site-directed mutagenesis, germ line transformation, and expression analysis of the Syn gene. It should be clear, however, that the current interpretation of the Western signals in fly head homogenates (Fig. 9) must remain tentative as long as direct protein sequence data, information on post-translational modifications, and selective mutants or transformants are unavailable.

\section{Tissue distributions of SYN isoforms}

The fact that nearly all synapses show the same relative staining intensity, whether the antibody used recognizes ORF1 or ORF2, indicates that small and large Drosophila synapsin homolog isoforms are expressed at abundance ratios similar to those shown in the Western blots, that is, approximately 4 to 1 . The low or absent expression in photoreceptors and some synapses in the medulla intriguingly corresponds to similar findings in the vertebrate retina, where lack of synapsins has been reported for "ribbon" synapses of photoreceptors and bipolar cells (DeCamilli et al., 1990; Mandell et al., 1990). In view of the many different aspects for which there is similarity or analogy in the structure and distribution of synapsins in vertebrates and of the Drosophila synapsin homolog, it seems quite likely that there also is a functional correspondence. The targeted deletion of the Syn gene therefore is presently attempted.

\section{REFERENCES}

Bähler M, Greengard P (1987) Synapsin I bundles F-actin in a phosphorylation-dependent manner. Nature 326:704-707.

Bähler M, Benfenati F, Valtorta F, Greengard P (1990) The synapsins and the regulation of synaptic function. Bioessays 12:259-263.

Beier H, Barciszewska M, Krupp G, Mitnacht R, Gross HJ (1984) UAG readthrough during TMV RNA translation: isolation and sequence of two tRNAs ${ }^{\text {Tyr }}$ with suppressor activity from tobacco plants. EMBO J 3:351-356.

Benfenati F, Valtorta F (1993) Synapsins and synaptic transmission. News Physiol Sci 8:18-23. 
Benfenati F, Valtorta F, Greengard P (1991) Computer modeling of synapsin I binding to synaptic vesicles and F-actin: implications for regulation of neurotransmitter release. Proc Natl Acad Sci USA $88: 575-579$.

Bienz M, Kubli E (1981) Wild-type tRNA ${ }^{\text {Tyr }}{ }_{\text {G }}$ reads the TMV RNA stop codon, but $\mathrm{Q}$ base- modified tRNA ${ }^{\mathrm{Tyr}}{ }_{\mathrm{Q}}$ does not. Nature 294:188-190.

Birnstiel ML, Busslinger M, Strub K (1985) Transcription termination and 3'processing: the end is in site. Cell 41:349-359.

Bongiovi ME, Ambron RT, Silverman A-J (1992) The morphological localization and biochemical characterization of a synapsin I-like antigen in the nervous system of Aplysia californica. J Neurosci Res 32:395-406.

Boyd L, Thummel CS (1993) Selection of CUG and AUG initiator codons for Drosophila E74A translation depends on downstream sequences. Proc Natl Acad Sci USA 90:9164-9167.

Buchner E, Buchner S, Crawford G, Mason WT, Salvaterra PM, Satelle DB (1986) Cholineacetyltransferase-like immunoreactivity in the brain of Drosophila melanogaster. Cell Tissue Res 246:57-62.

Cattaneo R (1991) Different types of messenger RNA editing. Annu Rev Genet 25:71-88.

Cavener DR (1987) Comparison of the consensus sequence flanking translational start sites in Drosophila and vertebrates. Nucleic Acids Res 1:1353-1360.

Ceccaldi P-E, Grohovaz F, Benfenati F, Chieregatti E, Greengard P, Valtorta F (1995) Dephosphorylated synapsin I anchors synaptic vesicles to actin cytoskeleton: an analysis by videomicroscopy. J Cell Biol 128:905-912.

Chin L-S, Li L, Ferreira A, Kosik KS, Greengard P (1995) Impairment of axonal development and of synaptogenesis in hippocampal neurons of synapsin I-deficient mice. Proc Natl Acad Sci USA 92:9230-9239.

DeCamilli P, Benfenati F, Valtorta F, Greengard P (1990) The synapsins. Annu Rev Cell Biol 6:433-460.

Feinberg AP, Vogelstein B (1983) A technique for radiolabeling DNA restriction endonuclease fragments to high specific activity. Anal Biochem 132:6-13.

Ferreira A, Han H-Q, Greengard P, Kosik KS (1995) Suppression of synapsin II inhibits the formation and maintenance of synapses in hippocampal culture. Proc Natl Acad Sci USA 92:9225-9229

Fischbach K-F, Dittrich APM (1989) The optic lobe of Drosophila melanogaster. I. A Golgi analysis of wildtype structure. Cell Tissue Res 258:441-475

Geller AI, Rich A (1980) A UAG termination suppression tRNA ${ }^{\text {Trp }}$ active in rabbit reticulocytes. Nature 283:41-46.

Hafen E, Levine M, Garber RL, Gehring WJ (1983) An improved in situ hybridization method for detection of ccllular RNAs in Drosophila tissue sections and its application for localizing transcripts of the homeotic Antennapedia gene complex. EMBO J 2:617-623.

Hall FL, Mitchell JP, Vulliet PR (1990) Phosphorylation of synapsin I at a novel site by proline-directed protein kinase. J Biol Chem 265:6944-6948.

Hatfield D (1985) Suppression of the termination codons in higher eukaryotes. Trends Biochem Sci 5:201-204.

Heimbeck G, Klagges B, Pflugfelder GO, Buchner S, Buchner E (1990) Molecular characterization of two Drosophila genes expressed in the adult brain. In: Brain - perception-cognition. (Elsner N, Roth G, eds) p 391. Stuttgart: Thieme.

Henikoff S (1987) Unidirectional digestion with exonuclease III in DNA sequence analysis. Methods Enzymol 155:156-165.

Huttner WB, Schiebler W, Greengard P, DeCamilli P (1983) Synapsin I (Protein I), a nerve terminal-specific phosphoprotein. III. Its association with synaptic vesicles studied in a highly purified synaptic vesicle preparation. J Cell Biol 96:1374-1388.

Jahn R, Südhof TC (1994) Synaptic vesicles and exocytosis. Annu Rev Neurosci 17:219-246.

Jan LY, Jan YN (1976) Properties of the larval neuromuscular junction in Drosophila melanogaster. J Physiol (Lond) 262:189-214.

Khyse-Andersson J (1984) Electroblotting of multiple gels. Biochem Biophys Methods 10:203.

Klagges B, Heimbeck G, Hotbauer A, Plugfelder GO, Godenschwege T, Reifegerste R, Schaupp M, Buchner S, Buchner E (1995) The Drosophila synapsin homolog gene. J Neurogenet 10:33.

Laemmli UK (1970) Cleavage of structural proteins during the assembly of the head of bacteriophage T4. Nature 227:680-685.
Li L, Chin L-S, Shupliakov O, Brodin L, Sihra TS, Hvalby O, Jensen V, Zheng D, McNamara JO, Greengard P, Andersen P (1995) Impairment of synaptic vesicle clustering and of synaptic transmission, and increased seizure propensity, in synapsin I-deficient mice. Proc Natl Acad Sci USA 92:9235-9239.

Llinas R, Gruner JA, Sugimori M, McGuinness TL, Greengard P (1991) Regulation by synapsin $\mathrm{I}$ and $\mathrm{Ca}^{2+} /$ calmodulin dependent protein $\mathrm{ki}$ nase II of neurotransmitter release in squid giant synapse. J Physiol (Lond) 436:257-282.

Mandell JW, Townes-Anderson E, Czernik AJ, Cameron R, Greengard P, DeCamilli P (1990) Synapsins in the vertebrate retina: absence from ribbon synapses and heterogeneous distribution among conventional synapses. Neuron 5:19-33.

Mitschulat $\mathrm{H}$ (1989) Dynamic properties of the $\mathrm{Ca}^{2+} /$ calmodulindependent protein kinase in Drosophila: identification of a synapsin I-like protein. Proc Natl Acad Sci USA 86:5988-5992.

Mount SM, Burks C, Hertz G, Stormo GD, White O, Fields C (1992) Splicing signals in Drosophila: intron size, information content, and consensus sequences. Nucleic Acids Res 20:4255-4262.

Peters JH, Baumgarten H (1990) Monoklonale Antikörper. Herstellung und Charakterisierung. Berlin: Springer.

Pieribone VA, Shupliakov O, Brodin L, Hilfiker-Rothenfluh S, Czernik AJ, Grecngard P (1995) Distinct pools of synaptic vesicles in neurotransmitter release. Nature 375:493-497.

Proudfoot NJ, Brownlee GG (1976) 3'Non-coding region sequences in eukaryotic messenger RNA. Nature 263:211-214.

Reichmuth C, Becker S, Benz K, Debel D, Reisch D, Heimbeck G, Hofbauer A, Klagges B, Pflugfelder GO, Buchner E (1995) The snap47 gene of Drosophila melanogaster codes for a novel conserved protein associated with synaptic terminals. Mol Brain Res $32: 45-54$.

Reifegerste R, Grimm S, Albert S, Lipski N, Heimbeck G, Hofbauer A Pflugfelder GO, Quack D, Reichmuth C, Schug B, Zinsmaier K, Buchner S, Buchner E (1993) An invertebrate calcium-binding protein of the calbindin subfamily: protein structure, genomic organization and expression pattern of the calbindin-32 gene of Drosophila. J Neurosci 13:2186-2198.

Rosahl TW, Geppert M, Spillane D, Herz J, Hammer RE, Melanka RC, Südhof TC (1993) Short-term synaptic plasticity is altered in mice lacking synapsin I. Cell 75:661-670.

Rosahl TW, Spillane D, Missler M, Herz J, Selig DK, Wolff JR, Hammer RE, Malenka RC, Südhof TC (1995) Essential functions of synapsins I and II in synaptic vesicle regulation. Nature $375: 488-493$

Ruano D, Lambolez B, Rossler J, Paternain AV, Lerma J (1995) Kainate receptor subunits expressed in single cultured hippocampal neurons: molecular and functional variants by RNA editing. Neuron 14:1009-1017.

Sambrock J, Fritsch EF, Mainatis T (1989) Molecular cloning, a laboratory manual. Cold Spring Harbor, NY: Cold Spring Harbor Laboratory.

Samson M-L, Lisbin MJ, White K (1995) Two distinct temperaturesensitive alleles at the elav locus of Drosophila are suppressed nonsense mutations of the same tryptophan codon. Genetics 141:1101-1111.

Sanger F, Nicklem S, Coulson AR (1977) DNA sequencing with chainterminating inhibitors. Proc Natl Acad Sci USA 74:5463-5467.

Scheller RH (1995) Membrane trafficking in the presynaptic nerve terminal. Neuron 14:893-897.

Schiebler W, Jahn R, Doucet J-P, Rothlein J, Greengard P (1986) Characterization of synapsin I binding to small synaptic vesicles. J Biol Chem $261: 8383-8390$

Senapathy J, Shapiro MB, Harris NL (1990) Splice junctions, branch point sites and exons: sequence statistics, identification and application to genome project. Methods Enzymol 183:252-258.

Smith DB, Johnson KS (1988) Single step purification of polypeptide expressed in Escherichia coli as fusions with glutathion S-transferase. Gene 67:31-40.

Sommer B, Köhler M, Sprengel R, Seeburg PH (1993) RNA editing in brain controls a determinant of ion flow in glutamate-gated channels. Cell 67:11-19.

Stcwart BA, Atwood HL, Renger JJ, Wang J, Wu C-W (1994) Improved stability of Drosophila larval neuromuscular preparations in haemolymph-like physiological solutions. J Comp Physiol [A] 175:179-191. 
Südhof TC (1990) The structure of the human synapsin I gene and protein. J Biol Chem 265:7849-7852.

Südhof TC (1995) The synaptic vesicle cycle: a cascade of protein-protein interactions. Nature 375:645-653.

Südhof TC, Czernik AJ, Kao H-T, Takei K, Johnston PA, Horiuchi A Kanazir SD, Wagner MA, Perin MS, DeCamilli P, Greengard P (1989) Synapsins: mosaics of shared and individual domains in a family of synaptic vesicle phosphoproteins. Science 245:1474-1480.

Sugihara H, Andrisani V, Salvaterra PM (1990) Drosophila choline acetyltransferase uses a non-AUG initiation codon and full length RNA is inefficiently translated. J Biol Chem 265:21714-21719.

Tautz D, Pfeifle C (1989) A non-radioactive in situ hybridization method for the localization of specific RNAs in Drosophila embryos reveals translational control of the segmentation gene hunchback. Chromosoma 98:81-85.
Valtorta F, lezzi N, Benfenati F, Lu B, Poo M, Greengard P (1995) Accelerated structural maturation induced by synapsin I at developing neuromuscular synapses of Xenopus laevis. Eur J Neurosci 7:261-270.

Washburn T, O'Tousa JE (1992) Nonsense suppression of the major rhodopsin gene of Drosophila. Genetics 130:585-595.

Xue F, Cooley L (1993) kelch encodes a component of intercellular bridges in Drosophila egg chambers. Cell 72:681-693.

Young RA, Davis RW (1985) Immunoscreening $\lambda$ gt11 recombinant DNA expression libraries. In: Genetic engineering 7 (Setlow J, Hollander A, eds), pp 29-41. New York: Plenum.

Zinsmaier K, Hofbauer A, Heimbeck G, Pflugfelder GO, Buchner S, Buchner E (1990) A cysteine-string protein is expressed in retina and brain of Drosophila. J Neurogenet 7:15-29. 